\title{
PENGARUH KUALITAS SISTEM, KUALITAS INFORMASI, PENGGUNAAN SISTEM, DAN KEPUASAN PENGGUNA TERHADAP DAMPAK INDIVIDUAL (STUDI EMPIRIS PADA BANK UMUM DI JAKARTA)
}

\author{
Ricche Khosasi dan Agustin Ekadjaja \\ Fakultas Ekonomi Universitas Tarumanagara \\ Email:aekadjaja@gmail.com
}

\begin{abstract}
The implementation of operational system is a necessity for the bank. However, the successful implementation of the system to the end-user of the systems have some little problems related to the end-user performance. The purpose of this research is to analyze and demonstrate empirically the effect of system quality, information quality, system use, and user satisfaction of the individual impact. The sample used by 75 respondents who were in the commercial bank in Jakarta. To answer the research hypothesis with IBM SPSS Statistic (Statistical Package for the Social Sciences) 21.0 software, multiple regression analysis is used in this test, after testing the assumption of classical test first. Based on the research results, it can be concluded that the system quality, information quality, system use, and user satisfaction have an effect to the individual impact. To get a better results, further research is recommended to add other variables to measure the effect of individual impact directly.
\end{abstract}

Keywords: system quality, information quality, system use, user satisfaction, individual impact

\begin{abstract}
Abstrak: Penerapan sistem operasional merupakan suatu keharusan bagi bank. Namun, keberhasilan pelaksanaan sistem untuk pengguna akhir dari sistem memiliki beberapa masalah kecil yang berkaitan dengan kinerja pengguna akhir. Tujuan dari penelitian ini adalah untuk menganalisis dan membuktikan secara empiris pengaruh kualitas sistem, kualitas informasi, penggunaan sistem, dan kepuasan pengguna dari dampak individual. Sampel yang digunakan sebanyak 75 responden yang berada di bank komersial di Jakarta. Untuk menjawab hipotesis penelitian dengan IBM SPSS Statistik (Statistical Package for Social Sciences) 21,0 software, analisis regresi berganda digunakan dalam tes ini, setelah menguji asumsi uji klasik pertama. Berdasarkan hasil penelitian, dapat disimpulkan bahwa kualitas sistem, kualitas informasi, penggunaan sistem, dan kepuasan pengguna berpengaruh terhadap dampak individual. Untuk mendapatkan hasil yang lebih baik, penelitian lebih lanjut disarankan untuk menambah variabel lain untuk mengukur efek dari dampak individual langsung.
\end{abstract}

Kata kunci: kualitas sistem, kualitas informasi, penggunaan sistem, kepuasan pengguna, dampak individual

\section{PENDAHULUAN}

Dalam era globalisasi, kemajuan teknologi komputer dan informasi tumbuh begitu pesat dan terus-menerus tanpa hambatan. Perkembangan teknologi dan penyampaian informasi juga diterapkan dalam sistem perbankan. Semua bank berlomba-lomba 
memberikan dan memperkenalkan pelayanan, tekonologi dan juga informasi yang berbasis online untuk melancarkan transaksi keuangan.

Salah satu sistem yang vital dalam bank adalah sistem informasi akuntansi. Sistem informasi akuntansi bank sangat mudah terbentuk dengan dasar yang kuat dari sistem operasional bank. Sistem operasional bank merupakan keseluruhan sistem yang berhubungan dengan kegiatan perbankan yang merupakan bagian dari sistem informasi akuntansi. Menurut Hall (2013:703) " because the operating system is common to all users, the larger the computer facility, the greater the scale of potential damage."

Semakin canggih teknologi, semakin tinggi masalah yang dihadapi yang diikuti dengan semakin kompleksnya penggunaan aplikasi. Menurut Janson dan Subramanian, dan Lucas, et al. dalam Istianingsih dan Wijanto (2008:51), masalah yang biasanya timbul dalam penggunaan aplikasi akuntansi adalah tidak kompatibelnya sistem dengan proses bisnis dan informasi yang diperlukan organisasi. Ketidaksesuaian tersebut menimbulkan masalah yang signifikan bagi pengguna akhir (end user).

Kesulitan teknis yang mengganggu dalam aplikasi seperti masalah interfacing dalam sistem, dan kesulitan hardware dapat membuat pengguna frustasi dan menurunkan tingkat kepuasan pengguna (Istianingsih dan Wijanto, 2008:51). Karena kesulitan yang mereka hadapi, maka kinerja dari pengguna sistem aplikasi akan secara otomatis menurun dari biasanya. Menurut Jumaili (2005:732) teknologi sistem informasi memengaruhi kinerja individu.

Keberhasilan sistem informasi tergantung dari bagaimana sistem tersebut diimplementasikan, kemudahan bagi pengguna, dan pemanfaatan teknologi yang digunakan. Menurut Montazemi; Bailey dan Pearson, Edstrom, Ives, Olson dan Baroudi dalam Komara (2005:837) menyatakan bahwa kepuasan pengguna sistem informasi dapat dijadikan sebagai tolak ukur dalam menilai keberhasilan sistem.

Keberhasilan implementasi aplikasi akuntansi bank harus didukung oleh keberhasilan aplikasi operasional yang merupakan bagian awal dari proses transaksi keuangan bank yang langsung berhubungan dengan pengguna akhir dan nasabah. Menurut Sugeng dan Nur Indriantoro dalam Rahmawati (2008:109) yang berpendapat bahwa perlu adanya model teoritis komprehensif yang kuat untuk mengukur kinerja individu baik secara langsung maupun tidak langsung melalui variabel-variabel yang signifikan. Banyak variabel dalam lingkungan sistem informasi yang memengaruhi kinerja pengguna baik secara langsung maupun tidak langsung (Abugabah, et al., 2009:3). Menurut Abugabah, et al. (2009:5) model yang paling banyak digunakan dalam penelitian keberhasilan sistem informasi adalah Technology Acceptance Model (TAM), the Task-Technology Fit model (TTF), and DeLone \& McLean model (D\&M).

Ruang Lingkup Penelitian. Penelitian ini dilakukan untuk meneliti sejauh mana pengaruh kualitas sistem, kualitas informasi, penggunaan sistem, dan kepuasan pengguna terhadap dampak individual yang sampai sekarang masih banyak faktor-faktor yang memengaruhi kinerja pengguna sistem informasi pada bank umum di Jakarta.

Bank umum yang diteliti dalam penelitian ini dipersempit dengan mengambil 5 (lima) bank dari harga saham tertinggi perlembarnya. Urutan bank yang dipilih berdasarkan harga saham bank tertinggi pada saat penutupan menurut Indeks Kompas100 (dalam Kompas, 21 November 2014) yaitu PT Bank Central Asia,Tbk dengan harga penutupan sebesar 13.250, PT Bank Rakyat Indonesia (Persero),Tbk dengan harga 
penutupan sebesar 11.125, PT Bank Mandiri (Persero),Tbk dengan harga penutupan sebesar 10.450, PT Bank Negara Indonesia (Persero),Tbk dengan harga penutupan sebesar 5.800, dan PT Bank Danamon Indonesia,Tbk dengan harga penutupan sebesar 4.270. Kuesioner dibagi sebanyak 20 eksemplar kepada setiap bank.

Variabel Penelitian. Variabel independen dalam penelitian ini adalah kualitas sistem (X1), kualitas informasi (X2), penggunaan sistem (X3), dan kepuasan pengguna (X4). Sedangkan variabel dependen adalah dampak individual (Y). Kualitas sistem (X1) adalah kualitas dari kombinasi perangkat keras (hardware) dan perangkat lunak (software) dalam sistem informasi yang diukur dari seberapa akurat dan efisien aplikasi operasional dapat menghasilkan informasi bagi pengguna. Kualitas informasi (X2) adalah kualitas output berupa informasi yang berkaitan dengan relevansi, ketepatan waktu, dan akurasi informasi yang dihasilkan sistem informasi. Penggunaan sistem (X3) yang dimaksud dalam penelitian ini adalah penggunaan aplikasi operasional oleh pengguna akhir atas kesadaran dan keinginan individu sendiri. Kepuasan pengguna (X4) adalah tanggapan dari pengguna akhir dari penggunaan aplikasi dan outputnya. Dampak individual (Y) dalam penelitian ini adalah dampak aplikasi operasional terhadap kinerja individu.

\section{KAJIAN TEORI}

Pengertian Sistem. Sistem menurut Hall (2013:782) adalah "group of two or more interrelated components or subsystems that serve a common purpose." Sedangkan menurut Romney dan Steinbart (2014:3) "a system is a set of two or more interrelated components that interact to achieve a goal." Menurut Mulyadi (2008:2) sistem adalah "sekelompok unsur yang erat berhubungan satu dengan lainnya, yang berfungsi bersamasama untuk mencapai tujuan tertentu." Marakas dan O'Brien (2013:3) "a system is a set of interrelated components, with a clearly defined boundary, working together to achieve a common set of objectives." Pengertian sistem secara keseluruhan dapat disimpulkan menjadi kumpulan dari beberapa komponen yang saling berhubungan atau berinteraksi untuk mencapai tujuan tertentu.

Pengertian Informasi. Menurut Jogiyanto (2005:8), informasi dapat didefinisikan sebagai hasil dari pengolahan data dalam suatu bentuk yang lebih berguna dan lebih berarti bagi penerimanya yang menggambarkan suatu kejadian-kejadian nyata yang digunakan untuk pengambilan keputusan. Melalui sistem informasi, data diolah menjadi informasi yang lebih bermanfaat dan berguna untuk pengguna akhir dalam pengambilan keputusan.

Marakas dan O'Brien (2013:32) informasi adalah "data that have been converted into a meaningful and useful context for specific end users." Gelinas, et al. (2012:18) menyatakan bahwa "information is data presented in a form that is useful in a decisionmaking activity." Menurut Romney dan Steinbart (2014:4) "information is data that have been organized to provide meaning and improve the decision-making process." Tiga tujuan fundamental informasi menurut Hall (2013:5) adalah: "a) to support the stewardship function of management, b) to support management decision making, c) to support the firm's day-to-day operations." Secara keseluruhan, informasi adalah 
sekumpulan data mentah yang diorganisir dan diproses sehingga mempunyai arti dan dampak bagi penerima informasi.

Pengertian Sistem Informasi. Hall (2013:5) "the information system is a set of formal procedures by which data are collected, stored, processed into information, and distributed to users. Hall (2013:5-7) mendefinisikan transaksi, transaksi keuangan, dan transaksi nonkeuangan adalah sebagai berikut:

"A transaction is an event that affects or is of interest to the organization and is processed by its information system as a unit of work. A financial transaction is an economic event that affects the assets and equities of the organization, is reflected in its accounts, and is measured in monetary terms. Nonfinancial transactions are events that do not meet the narrow definition of a financial transaction."

Sistem informasi menurut Romney dan Steinbart (2014:685) adalah "an organized way of collectiong, processing, managing, and reporting information so that an organization can achieve its objectives and goals. Formal informations systems have an explicit responsibility to produce information. An informal information system meets a need that is not satisfied by a formal channel and operates without formal designation of responsibility."

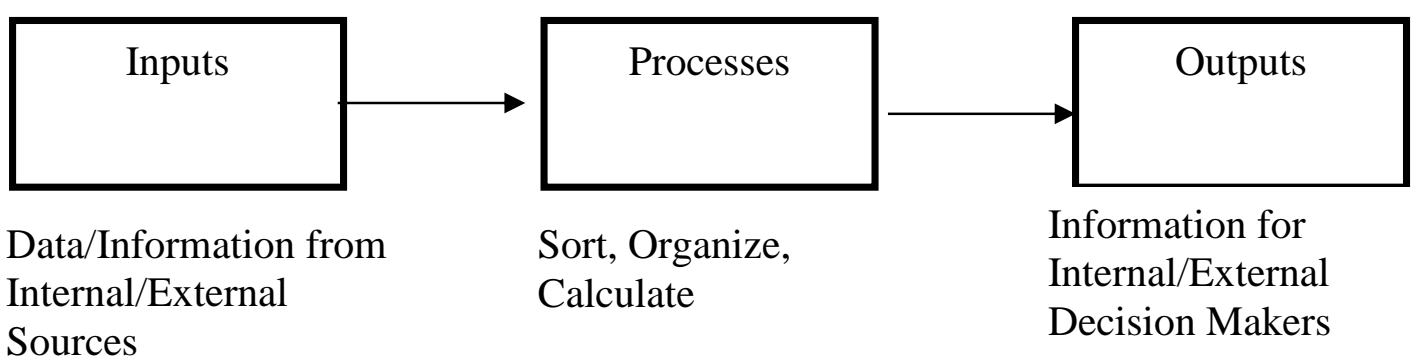

Gambar 1. Komponen Sistem Informasi

Pengertian Akuntansi. Romney dan Steinbart (2012:30) berpendapat bahwa, "Accounting is a data identification, collection, and storage process as well as an information development, measurement, and communication process." Menurut Warren et al. (2005:8) adalah "information system that provides reports to stakeholders about the economic activities and conditions of a business."

Menurut pendapat ahli di atas, pengertian akuntansi dapat disimpulkan menjadi sistem informasi yang menghasilkan informasi ekonomi yang berguna dalam pengambilan keputusan oleh para pengguna.

Pengertian Sistem Informasi Akuntansi. Menurut Romney dan Steinbart (2014:10) "accounting information system (AIS) is the intelligence-the information-providing vehicle—of the language." Hall (2013:765) "accounting information systems (AIS): specialized subset of information systems that processes financial transactions." Terdapat enam komponen dalam SIA menurut Romney dan Steinbart (2014:10) adalah: 
"1) The people who uses the system. 2) The procedures and instructions used to collect, process, and store data. 3) The data about the organization and its business activities. 4) The software used to process the data. 5) The information technology infrastructure, including the computers, peripheral devices, and network communications devices used in the AIS. 6) The internal controls and security measures that safeguard AIS data."

Keenam komponen SIA memungkinkan perusahaan untuk melaksanakan tiga fungsi penting yaitu dalam Hall (2013:10-11):

"1) Collect and store data about organizational activities, resources, and personnel. Organizations have a number of business processes, such as making a sale or purchasing raw materials, which are repeated frequently. 2) Transform data into information so management can plan, execute, control, and evaluate activities, resources, and personnel. 3) Provide adequate controls to safeguard the organization's assets and data."

Pengertian sistem informasi akuntansi dapat disimpulkan menjadi suatu sistem informasi yang merubah data ekonomi menjadi informasi akuntansi atau keuangan.

Sistem Operasional. Menurut Hall (2013:703) “operating system is the computer's control program. It allows users and their applications to share and access common computers resouces, such as processors, main memory, databases, and printers." Sedangkan menurut Romney dan Steinbart (2014:688) sistem operasinal (operating system) adalah

" a software program that controls the overall operation of a computer system. Its functions include controlling the execution of cumputer programs, scheduling, debugging, assigning storage areas, managing data, and controlling input and output."

Sistem operasional dapat disimpulkan menjadi suatu sistem yang mengendalikan hampir seluruh operasional dalam kegiatan komputerisasi.

Kualitas Sistem. Laudon dan Laudon (2012:530) "Quality is an indicator of how well the end result of a project satisfies the objectives specified by management." Negash, et al., (2003:759) "System quality is a measure of the information processing system itself." Menurut Panagopoulos (2010:82) kualitas sistem yaitu

"...the desired characteristics of the information system itself who produces the information, such as perceived usefulness, convenience, ease of use, portability, functionality, ease of learning and ability to integrated with other systems."

Kualitas sistem berfokus pada penggabungan hardware dan software. Kualitas sitem dapat dinilai dari karakteristik informasi pada sistem tersebut yang terdiri dari kemudahan penggunaan aplikasi, dan output yang dihasilkan tanpa bug dalam sistem.

Kualitas Informasi. Marakas dan O'Brien (2013:690) kualitas informasi adalah "The degree to which information has content, form, and time characteristics that give it value for specific end users." Menurut Jogiyanto (2005:10) Kualitas dari suatu informasi (Quality of Information) tergantung dari tiga hal, yaitu informasi harus akurat (Accurate), tepat pada waktunya (Timeliness), dan relevan (Relevance). 
Penggunaan Sistem. Menurut Seddon (1997:246) adalah "IS use means using the system. It is expected that resources such as human effort will be consumed as the system is used." Petter, et al. (2008:239) mendefinisikan penggunan sistem sebagai berikut "the degree and manner in which staff and customers utilize the capabilities of an information system. For example: amount of use, frequency of use, nature of use, appropriateness of use, extent of use, and purpose of use."

Kepuasan Pengguna. Kotler (2002:42) mendefinisikan kepuasan adalah perasaan senang atau kecewa seseorang yang muncul setelah membandingkan antara persepsi/kesannya terhadap kinerja (atau hasil) suatu produk dan harapan-harapannya. Petter, et al. (2008:239) kepuasan pengguna adalah "users' level of satisfaction with reports, Web sites, and support services."

Kepuasan pengguna mempunyai pengaruh besar dalam kinerja individu. Bisa diartikan kepuasan pengguna adalah suatu keadaan dimana pengguna (end user) merasa puas atau senang melakukan suatu kegiatan sehingga dampak dari kepuasan tersebut berupa peningkatan produktivitas atau peningkatan kinerja.

Dampak Individual. Dampak individual dalam penelitian ini berupa kinerja karyawan yang secara langsung maupun tidak langsung memengaruhi proses produktivitas karyawan. Kinerja individu sangat dipengaruhi oleh pengetahuan, kemampuan, kecakapan, dan harapan-har

apan (Widodo, 2005:80). Penelitian ini menggunakan dampak individual untuk mengukur kinerja pengguna sistem.

\section{Hipotesis Penelitian}

Hipotesis dalam penelitian ini adalah :

$\mathrm{Ha}_{1}$ : Kualitas sistem berpengaruh terhadap dampak individual.

$\mathrm{Ha}_{2}$ : Kualitas informasi berpengaruh terhadap dampak individual.

$\mathrm{Ha}_{3}$ : Penggunaan sistem berpengaruh terhadap dampak individual.

$\mathrm{Ha}_{4}$ : Kepuasan pengguna berpengaruh terhadap dampak individual.

\section{METODE}

Teknik Pengumpulan Data. Penelitian ini menggunakan data primer dengan metode pengumpulan data menggunakan kuesioner yang dikirimkan kepada responden. Pengukuran pertanyaan pada kuesioner menggunakan Skala Likert 5 (lima) angka yaitu mulai dari angka 5 (lima) untuk pendapat sangat setuju (SS) dan angka 1 (satu) untuk pendapat sangat tidak setuju (STS).

Teknik Pengolahan Data. Pengolahan data dilakukan dengan teknik regresi berganda untuk diolah dan membahas data yang telah diperoleh dan untuk menguji hipotesis yang diajukan. Pengujian yang dilakukan baik uji validitas, reliabilitas, normalitas, multikolonieritas, heteroskedastisitas, uji $\mathrm{F}$, uji t, regresi berganda dan analisis $\mathrm{R}$ dan $\mathrm{R}^{2}$ yang dilakukan dengan program IBM SPSS Statistic (Statistical Package for the Social Sciences) versi 21.0. Model regresi yang digunakan dalam penelitian ini adalah:

$$
Y=\alpha+\beta_{1} X_{1}+\beta_{2} X_{2}+\beta_{3} X_{3}+\beta_{4} X_{4}+\varepsilon
$$


Di mana: $\alpha=$ Konstanta; $\beta_{1}, \beta_{2}, \beta_{3}, \beta_{4}$, = Koefisien regresi; $X_{1}=$ Kualitas Sistem (SYSQUA); $X_{2}=$ Kualitas Informasi (INQUA); $X_{3}=$ Penggunaan Sisem (SYSUSE); $X_{4}$ $=$ Kepuasan pengguna $(\mathrm{USAT}) ; \mathrm{Y}=$ Dampak Individual $($ INDPACT); $\varepsilon=$ error terms

Analisis terhadap data yang ada selanjutnya diolah dengan menggunakan teknik analisis Statistik Deskriptif, Pengujian Instrumen Pengumpulan Data, dan Pengujian Asumsi Klasik.

Deskripsi Responden. Jumlah responden yang menjadi subjek penelitian berhubungan dengan penggunaan sistem operasional pada bank adalah seluruh karyawan bank (kantor cabang) adalah end-user yang menggunakan sistem operasional bank yang terdiri dari customer service, teller, supervisor atau seluruh karyawan yang terlibat dalam penggunaan sistem operasional bank.

Jumlah kuesioner yang dibagikan adalah sebanyak 100 kuesioner. Kuesioner yang kembali sebanyak 97 kuesioner dan terdapat 81 kuesioner yang diisi dengan lengkap, dimana 75 kuesioner dinyatakan valid atau sesuai dengan kriteria responden dan sisa 6 kuesioner tidak valid karena tidak sesuai dengan kriteria responden dan untuk sisa 16 kuesioner tidak diisi oleh responden. Posisi atau jabatan dari responden yang berhasil didapat dalam penyebaran kuesioner yaitu: teller, customer service, marketing, branch manager, supervisor, credit manager, credit analysis, integrated support officer (sekretaris regional), dan administrasi. Daftar responden penelitian adalah:

Tabel 1. Daftar Responden Penelitian

\begin{tabular}{|c|c|c|c|c|c|c|c|c|}
\hline \multirow{3}{*}{ No } & \multirow{3}{*}{$\begin{array}{l}\text { Bank Umum di } \\
\text { Jakarta }\end{array}$} & \multicolumn{7}{|c|}{ Jumlah Kuesioner } \\
\hline & & \multirow{2}{*}{ Terkirim } & \multicolumn{2}{|c|}{ Kembali } & \multicolumn{2}{|c|}{ Gugur } & \multicolumn{2}{|c|}{ Terpakai } \\
\hline & & & Jumlah & $\%$ & Jumlah & $\%$ & Jumlah & $\%$ \\
\hline 1. & $\begin{array}{l}\text { PT Bank Central } \\
\text { Asia Tbk }\end{array}$ & 20 & 19 & 19 & 1 & 1 & 18 & 18 \\
\hline 2. & $\begin{array}{l}\text { PT Bank Rakyat } \\
\text { Indonesia (Persero) } \\
\text { Tbk }\end{array}$ & 20 & 19 & 19 & 8 & 8 & 12 & 12 \\
\hline 3. & $\begin{array}{l}\text { PT Bank Mandiri } \\
\text { (Persero) Tbk }\end{array}$ & 20 & 20 & 20 & 7 & 7 & 11 & 11 \\
\hline 4. & $\begin{array}{l}\text { PT Negara Indonesia } \\
\text { (Persero) Tbk }\end{array}$ & 20 & 19 & 19 & 6 & 6 & 14 & 14 \\
\hline 5. & $\begin{array}{l}\text { PT Bank Danamon } \\
\text { Indonesia Tbk }\end{array}$ & 20 & 20 & 20 & 0 & 0 & 20 & 20 \\
\hline Total & & 100 & 97 & 97 & 22 & 22 & 75 & 75 \\
\hline
\end{tabular}




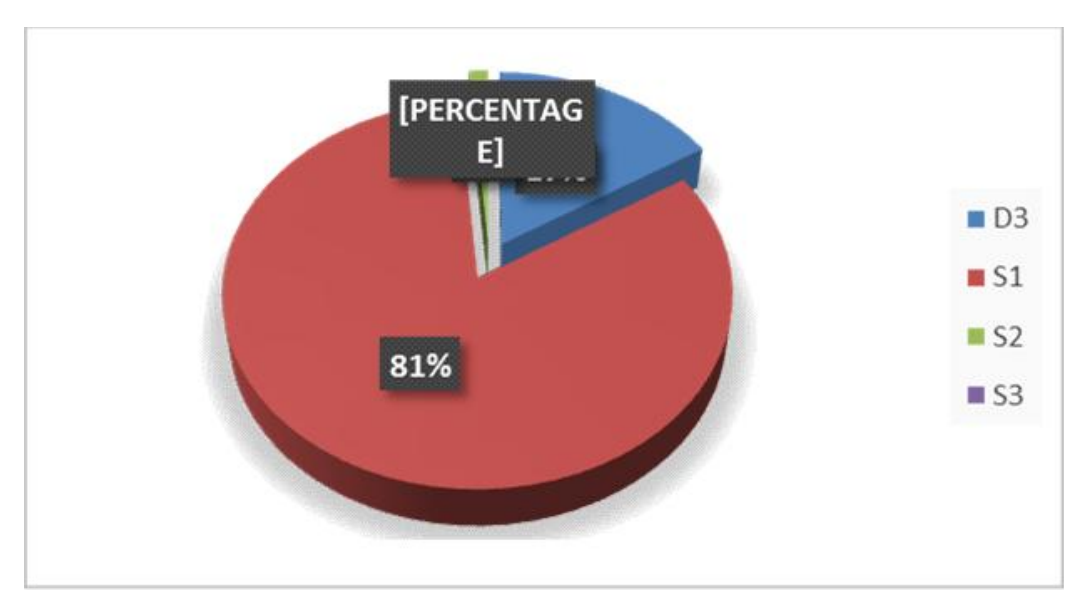

Gambar 2. Diagram Responden Menurut Pendidikan Sumber: Hasil penelitian olahan peneliti

Tabel 2. Gambaran Umum Profil (Karakteristik) Responden

\begin{tabular}{|c|c|c|c|}
\hline Keterangan & Kriteria & Jumlah & Persentase $(\%)$ \\
\hline \multirow{3}{*}{ Jenis Kelamin } & Laki-laki & 26 & 35 \\
\hline & Perempuan & 49 & 65 \\
\hline & Total & 75 & $100 \%$ \\
\hline \multirow{5}{*}{ Rentang Usia } & $21-25$ tahun & 48 & 64 \\
\hline & 26-30 tahun & 22 & 29 \\
\hline & 31-35 tahun & 0 & 0 \\
\hline & $>36$ tahun & 5 & 7 \\
\hline & Total & 75 & $100 \%$ \\
\hline \multirow{4}{*}{ Lama Bekerja } & $<1$ tahun & 0 & 0 \\
\hline & 1-3 tahun & 61 & 81 \\
\hline & $>3$ tahun & 14 & 19 \\
\hline & Total & 75 & $100 \%$ \\
\hline \multirow{5}{*}{$\begin{array}{l}\text { Pendidikan } \\
\text { Terakhir }\end{array}$} & D3 & 13 & 17 \\
\hline & $\mathrm{S} 1$ & 61 & 81 \\
\hline & $\mathrm{S} 2$ & 1 & 1 \\
\hline & S3 & 0 & 0 \\
\hline & Total & 75 & $100 \%$ \\
\hline \multirow{10}{*}{ Jabatan } & Teller & 34 & 45 \\
\hline & Customer Service & 17 & 23 \\
\hline & Marketing & 15 & 20 \\
\hline & Supervisor & 3 & 4 \\
\hline & Branch Manager & 2 & 3 \\
\hline & Credit Manager & 1 & 1 \\
\hline & Credit Analysis & 1 & 1 \\
\hline & $\begin{array}{l}\text { Integrated Support } \\
\text { Officer }\end{array}$ & 1 & 1 \\
\hline & Administrasi & 1 & 1 \\
\hline & Total & 75 & $100 \%$ \\
\hline
\end{tabular}


Tabel menggambarkan mengenai data demografi dari hasil kuesioner yang berisikan informasi antara lain mengenai jenis kelamin, usia, lama bekerja, pendidikan terakhir, dan jabatan.

\section{HASIL DAN PMBAHASAN}

Statistik Deskriptif. Statistik deskriptif digunakan untuk memberikan penjelasan gambaran umum demografi responden penelitian dan gambaran tentang variabel-variabel penelitian untuk mengetahui frekuensi distribusi absolut. Hasil perhitungan statistic deskriptif untuk masing-masing indikator (pertanyaan) yakni kualitas sistem yang disingkat menjadi SYSQUA, kualitas informasi yang disingkat menjadi INQUA, penggunaan sistem yang disingkat menjadi SYSUSE, kepuasan pengguna yang disingkat menjadi USAT, dan Dampak Individual yang disingkat menjadi INDPACT.

Tabel 3. Descriptive Statistic

\begin{tabular}{|l|c|c|c|c|c|}
\hline & $\mathrm{N}$ & Minimum & Maximum & Mean & Std. Deviation \\
\hline SYSQUA1 & 75 & 2.00 & 5.00 & 4.1333 & .64375 \\
SYSQUA2 & 75 & 1.00 & 5.00 & 3.7733 & .79820 \\
SYSQUA3 & 75 & 1.00 & 5.00 & 3.6000 & .98639 \\
SYSQUA4 & 75 & 1.00 & 5.00 & 3.5733 & .85698 \\
SYSQUA5 & 75 & 2.00 & 5.00 & 3.7200 & .70825 \\
SYSQUA6 & 75 & 2.00 & 5.00 & 3.6267 & .85065 \\
SYSQUA7 & 75 & 2.00 & 5.00 & 3.5600 & .85803 \\
SYSQUA8 & 75 & 2.00 & 5.00 & 4.0800 & .56377 \\
SYSQUA9 & 75 & 2.00 & 5.00 & 3.7333 & .55345 \\
SYSQUA10 & 75 & 2.00 & 5.00 & 3.6800 & .61863 \\
SYSQUA11 & 75 & 2.00 & 5.00 & 3.7333 & .70391 \\
\hline SYSQUA12 & 75 & 2.00 & 5.00 & 3.7467 & .75504 \\
\hline SYSQUA13 & 75 & 2.00 & 5.00 & 3.7333 & .74132 \\
\hline SYSQUA14 & 75 & 2.00 & 5.00 & 4.0000 & .77110 \\
Valid N (listwise) & 75 & & & & \\
INQUA1 & 75 & 2.00 & 5.00 & 3.9200 & .73079 \\
INQUA2 & 75 & 2.00 & 5.00 & 3.8667 & .75933 \\
INQUA3 & 75 & 2.00 & 5.00 & 3.8800 & .71584 \\
INQUA4 & 75 & 2.00 & 5.00 & 3.8133 & .65126 \\
INQUA5 & 75 & 3.00 & 5.00 & 3.9333 & .60030 \\
INQUA6 & 75 & 2.00 & 5.00 & 3.7200 & .64849 \\
Valid N (listwise) & 75 & & & & \\
SYSUSE1 & 75 & 2.00 & 5.00 & 3.9867 & .72584 \\
SYSUSE2 & 75 & 1.00 & 5.00 & 3.9067 & .75647 \\
SYSUSE3 & 75 & 1.00 & 5.00 & 3.8400 & .83892 \\
SYSUSE4 & 75 & 3.00 & 5.00 & 3.9333 & .70391 \\
SYSUSE5 & 75 & 2.00 & 5.00 & 3.9200 & .69282 \\
\hline Valid N (listwise) & 75 & \multicolumn{5}{|}{} & .74204 \\
USAT1 & 75 & 2.00 & 5.00 & 3.8267 & .68445 \\
USAT2 & 75 & 2.00 & 5.00 & 3.8667 & \\
\hline
\end{tabular}




$\begin{array}{llllll}\text { USAT3 } & 75 & 2.00 & 5.00 & 3.8533 & .63017 \\ \text { USAT4 } & 75 & 1.00 & 5.00 & 3.8267 & .76004 \\ \text { USAT5 } & 75 & 2.00 & 5.00 & 3.7600 & .69438 \\ \text { Valid N (listwise) } & 75 & & & & \\ \text { INDPACT1 } & 75 & 3.00 & 5.00 & 3.8667 & .64375 \\ \text { INDPACT2 } & 75 & 2.00 & 5.00 & 3.8400 & .61600 \\ \text { INDPACT3 } & 75 & 3.00 & 5.00 & 3.9733 & .67730 \\ \text { INDPACT4 } & 75 & 3.00 & 5.00 & 3.9467 & .63445 \\ \text { INDPACT5 } & 75 & 3.00 & 5.00 & 4.0400 & .62472 \\ \text { Valid N (listwise) } & 75 & & & & \end{array}$

Hasil Tabel 3 menunjukkan angka rata-rata sebesar > 3.5 yang bisa diinterpretasikan bahwa responden cenderung merasakan adanya kualitas terhadap sistem yang digunakan, sistem yang digunakan memberikan informasi yang cukup, responden cukup memadai dan ingin atau berniat menggunakan sistem operasional terkait yang dapat dilihat dengan nilai rata-rata yang mendekati nilai 4 (Setuju), responden cukup puas dengan sistem yang sedang digunakan sekarang, dan sistem yang digunakan saat ini cukup memengaruhi kinerja responden.

Uji Reliabilitas. Uji reliabilitas dilakukan terhadap item pertanyaan yang dinyatakan valid. Reliabilitas adalah alat untuk mengukur suatu kuesioner yang merupakan indikator dari variabel atau konstruk (Ghozali, 2011:47). Kuesioner dikatakan reliabel jika jawaban seseorang dari waktu ke waktu adalah stabil atau konsisten.

Hasil pengujian reliabilitas setiap indikator:

Tabel 4. Reliability Statistics

\begin{tabular}{cccc}
\hline Variable & Cronbach's Alpha & $\begin{array}{c}\text { Cronbach's Alpha } \\
\text { Based on Standardized } \\
\text { Items }\end{array}$ & N of Items \\
\hline SYSQUA & .832 & .834 & 14 \\
INQUA & .807 & .808 & 6 \\
SYSUSE & .819 & .821 & 5 \\
USAT & .846 & .850 & 5 \\
INDPACT & .839 & .838 & 5 \\
\hline
\end{tabular}

Sumber: output IBM SPSS versi 21.0

Berdasarkan hasil uji reliabilitas pada tabel yang telah dibahas, terlihat bahwa semua variabel penelitian merupakan variabel yang reliabel. Hal ini dikarenakan nilai dari masing-masing Cronbach's Alpha yang memenuhi kriteria $>0.70$ atau $>70 \%$.

Uji Validitas. Validitas adalah ketepatan alat ukur penelitian yang berhubungan dengan isi atau arti sebenarnya apa yang diukur dalam variabel penelitian. Suatu instrument dikatakan valid apabila memiliki kemampuan mengukur apa yang seharusnya diukur. Uji validitas dalam penelitian ini menggunakan rumus n-k-1 (degree of freedom) untuk menentukan nilai $r$ table product moment. Suatu pernyataan dikatakan valid apabila $r$ hitung (corrected item-total correlation) pada tabel item-total statistics lebih besar dari nilai $r$ table products moments. 
Penelitian ini menguji validitas dari variabel-valiabel laten Kualitas Sistem (X1), Kualitas Informasi (X2), Penggunaan Sistem (X3), Kepuasan pengguna (X4), dan Dampak Individual (Y). Degree of Freedom dalam penelitian ini dapat diperoleh dengan perhitungan sebagai berikut: $\mathrm{n}-\mathrm{k}-1=75-4-1=70$

Di mana: $\mathrm{n}=$ banyaknya sampel yang dapat digunakan; $\mathrm{k}=$ jumlah variabel dependen $(\mathrm{X})$

Tabel 5. Simpulan Uji Validitas Setiap Indikator

\begin{tabular}{lccc}
\hline \multicolumn{1}{c}{ Indikator } & $\begin{array}{c}\text { Corrected Item-Total } \\
\text { Correlation }\end{array}$ & $\begin{array}{c}\text { r critics } \\
\text { sig. } 5 \%\end{array}$ & Simpulan \\
\hline SYSQUA1 & 0.236 & 0.235 & Valid \\
SYSQUA2 & 0.474 & 0.235 & Valid \\
SYSQUA3 & 0.438 & 0.235 & Valid \\
SYSQUA4 & 0.471 & 0.235 & Valid \\
SYSQUA5 & 0.570 & 0.235 & Valid \\
SYSQUA6 & 0.490 & 0.235 & Valid \\
SYSQUA7 & 0.611 & 0.235 & Valid \\
SYSQUA8 & 0.615 & 0.235 & Valid \\
SYSQUA9 & 0.295 & 0.235 & Valid \\
SYSQUA10 & 0.368 & 0.235 & Valid \\
SYSQUA11 & 0.439 & 0.235 & Valid \\
SYSQUA12 & 0.680 & 0.235 & Valid \\
SYSQUA13 & 0.505 & 0.235 & Valid \\
SYSQUA14 & 0.351 & 0.235 & Valid \\
INQUA1 & 0.646 & 0.235 & Valid \\
INQUA2 & 0.558 & 0.235 & Valid \\
INQUA3 & 0.558 & 0.235 & Valid \\
INQUA4 & 0.536 & 0.235 & Valid \\
INQUA5 & 0.593 & 0.235 & Valid \\
INQUA6 & 0.512 & 0.235 & Valid \\
SYSUSE1 & 0.491 & 0.235 & Valid \\
SYSUSE2 & 0.674 & 0.235 & Valid \\
SYSUSE3 & 0.600 & 0.235 & Valid \\
SYSUSE4 & 0.530 & 0.235 & Valid \\
SYSUSE5 & 0.785 & 0.235 & Valid \\
USAT1 & 0.645 & 0.235 & Valid \\
USAT2 & 0.733 & 0.235 & Valid \\
USAT3 & 0.738 & 0.235 & Valid \\
USAT4 & 0.546 & 0.235 & Valid \\
USAT5 & 0.630 & 0.235 & Valid \\
INDPACT1 & 0.628 & 0.235 & Valid \\
INDPACT2 & 0.627 & 0.235 & Valid \\
INDPACT3 & 0.740 & 0.235 & Valid \\
INDPACT4 & 0.698 & & \\
INDPACT5 & 0.524 & & \\
& & 0.235 & \\
& & &
\end{tabular}


Uji Normalitas. Model pengujian normalitas dalam penelitian ini menggunakan uji statistik non-parametrik Kolmogorov-Smirnov (K-S). Hasil Uji K-S dapat dilihat pada Asymp. Sig (2-tailed), jika data menunjukan hasil $>0.05$ maka data residual berdistribusi normal, dan jika hasil Asymp. Sig (2-tailed) < 0.05 maka data residual tidak berdistribusi normal.

Berikut disajikan hasil output SPSS untuk uji normalitas Kolmogorov-Smirnov:

Tabel 6. Hasil Uji Normalitas Kolmogorov-Smirnov One-Sample Kolmogorov-Smirnov Test

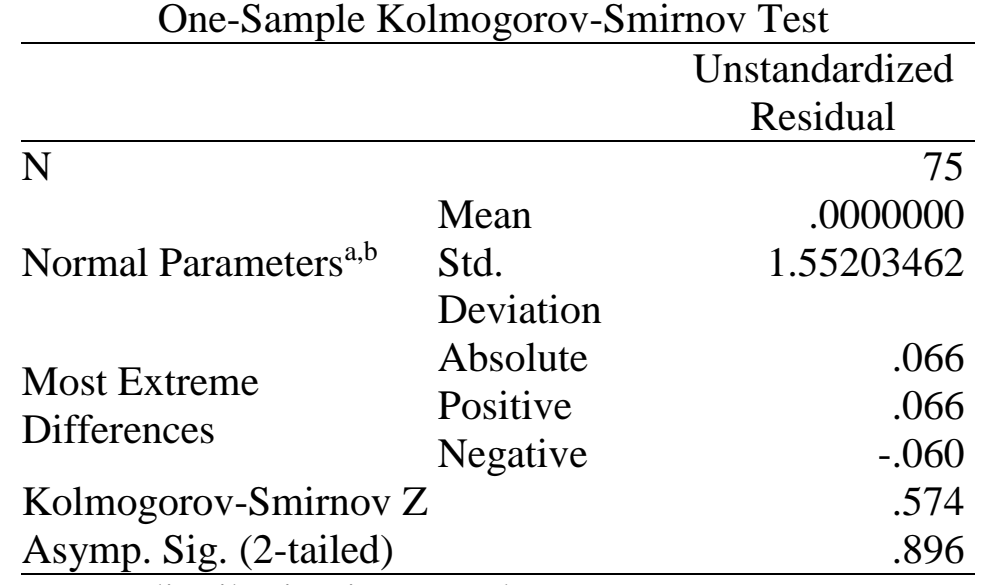

a. Test distribution is Normal.

b. Calculated from data.

Sumber: output IBM SPSS versi 21.0

Berdasarkan hasil uji Kolmogorov-Smirnov nilai Kolmogorov-Smirnov Z adalah 0.575 dan signifikan pada 0.896 atau dapat disimpulkan bahwa maka data residual berdistribusi normal yang dilihat dari nilai Asymp. Sig. (2-tailed) yang menunjukkan angka 0.896 atau > 0.05 .

Uji Multikolonieritas. Tujuan dari uji multikolonieritas adalah untuk mengetahui apakah model regresi ditemukan adanya korelasi antar variabel bebas (independen). Model regresi yang baik seharusnya tidak terjadi korelasi di antara variabel independen. Model regresi yang digunakan untuk uji multikolonieritas adalah dengan menggunakan Variance Inflation Factor (VIF). Batas dari VIF adalah 10 dan nilai tolerance kurang dari 0.1 atau $V I F>10$ maka antara variabel independen terdapat multikolinearitas dan jika VIF $\leq 10$ maka tidak ada korelasi antara variabel independen.

Tabel 7. Hasil Uji Multikolonieritas

Coefficients $^{\text {a }}$

\begin{tabular}{|c|c|c|c|c|c|c|c|c|}
\hline \multirow{2}{*}{\multicolumn{2}{|c|}{ Model }} & \multicolumn{2}{|c|}{$\begin{array}{c}\text { Unstandardized } \\
\text { Coefficients }\end{array}$} & $\begin{array}{l}\text { Standardized } \\
\text { Coefficients }\end{array}$ & \multirow[b]{2}{*}{$\mathrm{t}$} & \multirow[b]{2}{*}{ Sig. } & \multicolumn{2}{|c|}{ Collinearity Statistics } \\
\hline & & $\mathrm{B}$ & Std. Error & Beta & & & Tolerance & VIF \\
\hline 1 & (Constant) & -.159 & 2.068 & & -.077 & .939 & & \\
\hline
\end{tabular}




\begin{tabular}{llllllll}
\hline \hline & & & & & & \\
SYSQUA & .128 & .041 & .303 & 3.126 & .003 & .590 & 1.696 \\
INQUA & .154 & .070 & .182 & 2.206 & .031 & .813 & 1.230 \\
SYSUSE & .275 & .096 & .313 & 2.858 & .006 & .461 & 2.168 \\
USAT & .216 & .080 & .239 & 2.696 & .009 & .701 & 1.426 \\
\hline
\end{tabular}

a. Dependent Variable: INDPACT

Sumber: output IBM SPSS versi 21.0

Hasil menunjukkan nilai VIF dalam tabel Collinearity Statistics untuk masingmasing variabel $\leq 10$ dengan kesimpulan bahwa tidak ada korelasi antara variabel independen.

Uji Heteroskedastisitas. Tujuan dilakukannya pengujian heteroskedastisitas adalah untuk menguji dalam model regresi terjadi ketidaksamaan variance dari residual satu pengamatan ke pengamatan lain. Uji heteroskedastisitas yang digunakan dalam penelitian ini adalah uji Glejser. Model regresi dikatakan tidak mengandung Heteroskedastisitas jika nilai probabilitas diatas 0.05 atau 5\% (Ghozali, 2011:143)

Menurut Gurajati, 2003 dalam (Ghozali, 2011:142) menyatakan "Glejser mengusulkan untuk meregres nilai absolut residual terhadap variabel independen" dengan persamaan regresi sebagai berikut:

$$
|\mathrm{Ut}|=\alpha+\beta \mathrm{Xt}+\mathrm{vt}
$$

Rumus absolut tersebut dimasukkan kedalam program SPSS versi 21.0 dengan regresi variabel (ABSREG) sebagai variabel dependen dan variabel SYSQUA, INQUA, SYSUSE, dan USAT sebagai variabel independen sehingga menghasilkan persamaan regresi sebagai berikut:

$$
\text { ABSRES = b0+ b1 SYSQUA +b2 INQUA + b3 SYSUSE + b4 USAT }
$$

Berikut disajikan hasil uji heteroskedastisitas:

\begin{tabular}{|c|c|c|c|c|c|c|}
\hline \multicolumn{7}{|c|}{ Coefficients $^{\mathbf{a}}$} \\
\hline & \multirow[b]{2}{*}{ Model } & \multicolumn{2}{|c|}{$\begin{array}{c}\text { Unstandardized } \\
\text { Coefficients }\end{array}$} & \multirow{2}{*}{$\begin{array}{c}\text { Standardized } \\
\text { Coefficients } \\
\text { Beta }\end{array}$} & \multirow[b]{2}{*}{$\mathrm{t}$} & \multirow[b]{2}{*}{ Sig. } \\
\hline & & B & Std. Error & & & \\
\hline \multirow{5}{*}{1} & (Constant) & 1.165 & 1.203 & & .969 & .336 \\
\hline & SYSQUA & .010 & .024 & .067 & .432 & .667 \\
\hline & INQUA & -.003 & .041 & -.010 & -.077 & .939 \\
\hline & SYSUSE & .017 & .056 & .054 & .310 & .757 \\
\hline & USAT & -.038 & .047 & -.115 & -.813 & .419 \\
\hline
\end{tabular}

Tabel 8. Hasil Uji Heteroskedastisitas

a. Dependent Variable: ABSRES

Sumber: output IBM SPSS versi 21.0

Nilai Sig. yakni setiap variabel yang diuji atau variabel kualitas sistem (SYSQUA) sebesar, kualitas informasi (INQUA) sebesar, penggunaan sistem sebesar (SYSUSE), dan kepuasan pengguna (USAT) sebesar. Masing-masing mempunyai nilai Sig. yang diatas tingkat kepercayaan 5\%. Jadi, dapat disimpulkan model regresi tidak mengandung Heteroskedastisitas. 
Pengujian Hipotesis. Model yang dinyatakan baik untuk alat prediksi apabila telah mempunyai sifat-sifat Best Linear Unbiased Estimator (BLUE). Penelitian ini menggunakan regresi berganda sebagai dasar alat statistic untuk menguji hipotesis. Model regresi berganda yang digunakan dalam penelitian ini disajikan dalam persamaan berikut:

$$
Y=\alpha+\beta_{1} X_{1}+\beta_{2} X_{2}+\beta_{3} X_{3}+\beta_{1} X_{4}+\varepsilon
$$

Di mana: $\alpha=$ Konstanta; $\beta_{1}, \beta_{2}, \beta_{3}, \beta_{4}$, = Koefisien regresi; $X_{1}=$ Kualitas Sistem (SYSQUA); $\mathrm{X}_{2}=$ Kualitas Informasi (INQUA); $\mathrm{X}_{3}=$ Penggunaan Sisem (SYSUSE); $\mathrm{X}_{4}$ $=$ Kepuasan Pengguna (USAT); Y = Dampak Individual (INDPACT); $\varepsilon=$ error terms

Hubungan antar variabel independen dengan variabel dependen diuji pada tingkat signifikan $5 \%$.

Tabel 9. Model Persamaan Regresi

\section{Coefficients $^{\mathrm{a}}$}

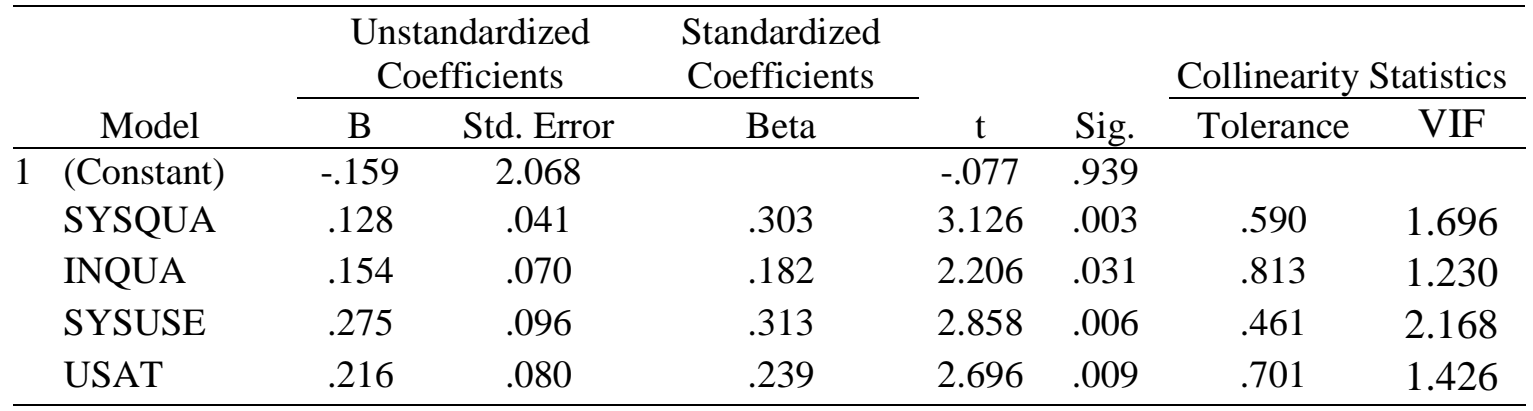

Dependent Variable: INDPACT

Sumber: output IBM SPSS versi 21.0

Berdasarkan hasil persamaan regresi yang terbentuk adalah:

$$
\begin{gathered}
Y=\alpha+\beta_{1} X_{1}+\beta_{2} X_{2}+\beta_{3} X_{3}+\beta_{4} X_{4}+\varepsilon \\
Y=-0.159+0.128 X_{1}+0.154 X_{2}+0.275 X_{3}+0.216 X_{4}+\varepsilon
\end{gathered}
$$

Arti dari koefisien konstanta -0.159 adalah jika $\mathrm{X}_{1}, \mathrm{X}_{2}, \mathrm{X}_{3}$, dan $\mathrm{X}_{4}$ adalah nol maka kepatuhan wajib pajak nilainya negatif yaitu -0.159 . Variabel $\mathrm{X}_{1}$ (Kualitas Sistem atau disingkat menjadi SYSQUA) diperoleh $\beta_{1}$ sebesar 0.128 artinya setiap peningkatan nilai kualitas sistem sebesar satu satuan maka nilai dampak individual juga akan meningkat sebesar 0.128. Hal ini menunjukkan kualitas sistem yang baik akan meningkatkan dampak individual pengguna akhir. Variabel $\mathrm{X}_{2}$ (Kualitas Informasi atau disingkat menjadi INQUA) dengan $\beta_{2}$ sebesar 0.154 artinya setiap peningkatan nilai kualitas informasi sebesar satu satuan makan nilai dampak individual juga akan meningkat sebesar 0.154. Hal ini menunjukkan kualitas informasi yang diperoleh pengguna akan meningkatkan dampak individual pengguna dalam sistem tersebut. Variabel $X_{3}$ (Penggunaan Sistem atau disingkat menjadi SYSUSE) dengan $\beta_{3}$ sebesar 0.275 artinya setiap peningkatan nilai penggunaan sistem sebesar satu satuan maka nilai dampak individual juga akan meningkat sebesar 0.275. Hal ini menunjukkan penggunaan sistem juga ikut meningkatkan dampak individual pengguna. Variabel $\mathrm{X}_{4}$ (Kepuasan Pengguna) dengan $\beta_{4}$ sebesar 0.216 artinya setiap peningkatan nilai kepuasan pengguna sebesar satu satuan maka nilai dampak individual juga akan meningkat sebesar 0.216. Hal ini menunjkkan kepuasan pengguna meningkatkan dampak individual pengguna sistem. 
Uji F Simultan. Pengujian ini adalah untuk mengetahui hubungan-hubungan antar variabel independen berpengaruh dengan variabel dependen secara simultan atau bersamasama. Jika nilai sig. < 0.05 maka Ho ditolak dan Ha diterima, dengan arti ada pengaruh antara variabel independen terhadap variabel dependen secara simultan. Jika nilai sig. > 0.05 maka Ho diterima dan Ha ditolak dengan arti terdapat pengaruh antara variabel independen dengan variabel dependen secara simultan.

Kriteria yang digunakan adalah:

Ho: Kualitas sistem, kualitas Informasi, penggunaan sistem, dan kepuasan pengguna tidak berpengaruh terhadap dampak individual.

Ha: Kualitas sistem, kualitas informasi, penggunaan sistem, dan kepuasan pengguna berpengaruh terhadap dampak individual.

Tabel 10. Hasil Uji F

\begin{tabular}{llrrrrr}
\multicolumn{7}{c}{ ANOVA $^{\mathbf{a}}$} \\
\hline Model & \multicolumn{1}{c}{ Sum of Squares } & \multicolumn{1}{c}{ df } & Mean Square & F & \multicolumn{1}{c}{ Sig. } \\
\hline & Regression & 282.415 & 4 & 70.604 & 27.726 & $.000^{\mathrm{b}}$ \\
1 & Residual & 178.252 & 70 & 2.546 & & \\
& Total & 460.667 & 74 & & & \\
\hline
\end{tabular}

a. Dependent Variable: INDPACT

b. Predictors: (Constant), USAT, SYSQUA, INQUA, SYSUSE

Sumber: output IBM SPSS versi 21.0

Hasil pengujian model hubungan variabel independen secara simultan dengan variabel dependen diperoleh nilai $\mathrm{F}$ sebesar 27.726 dengan probabilitas signifikansi sebesar 0.000 .

Uji t Parsial (t-test). Pengujian ini dilakukan untuk mengetahui hubungan secara parsial variabel-variabel independen terhadap variabel dependen atau hubungan kualitas sistem, kualitas informasi, penggunaan sistem, dan kepuasan pengguna terhadap dampak individual.

Tabel 11. Hasil Uji t (t-test)

Coefficients $^{\mathrm{a}}$

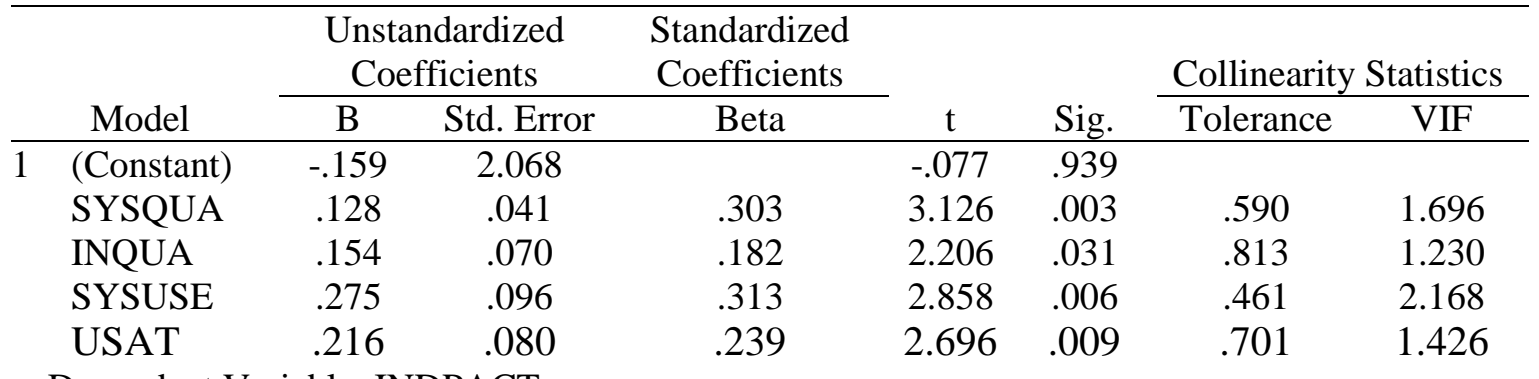

a. Dependent Variable: INDPACT

Sumber: output IBM SPSS versi 21.0 
Analisis Korelasi Ganda $(\mathbf{R})$ dan Uji Koefisien Determinasi $\left(\mathbf{R}^{2}\right)$. Analisis korelasi ganda $(\mathrm{R})$ digunakan untuk mengetahui apakah terdapat hubungan antara dua atau lebih variabel independen terhadap variabel dependen dan seberapa kuat hubungan tersebut. Uji koefisien determinasi $\left(\mathrm{R}^{2)}\right.$ dilakukan dengan maksud untuk mengetahui seberapa besar persentase variabel dependen dapat menjelaskan pengaruhnya terhadap variabel dependen. Berikut disajikan hasil perhitungan uji Korelasi Ganda pada data primer yang diolah dengan IBM SPSS v21.0:

Tabel 12. Hasil Uji Koefisien Determinasi

\begin{tabular}{ccccc}
\multicolumn{5}{c}{ Model Summary $^{\mathbf{b}}$} \\
\hline Model & $\mathrm{R}$ & $\mathrm{R}$ Square & Adjusted R Square & Std. Error of the Estimate \\
\hline 1 & $.783^{\mathrm{a}}$ & .613 & .591 & 1.59576 \\
\hline
\end{tabular}

a. Predictors: (Constant), USAT, SYSQUA, INQUA, SYSUSE

b. Dependent Variable: INDPACT

Sumber: output IBM SPSS versi 21.0

Berdasarkan hasil uji Koefisien Determinasi dengan IBM SPSS v21.0 terhadap data primer yang diperoleh, maka dapat disimpulkan dari R hitung sebesar 0.783 yang dapat diartikan terdapat hubungan yang kuat antara variabel independen dengan variabel dependen. Demikian juga dari hasil hitung Adjusted $R$ Square sebesar 0.591 atau sebesar $59.10 \%$ dari variabel dependen (Dampak Individual) dapat dijelaskan oleh variabel independen (Kualitas Sistem, Kualitas Informasi, Penggunaan Sistem, Kepuasan pengguna). Sedangkan sisanya $40.90 \%$ dijelaskan oleh variabel lain yang tidak diajukan dalam penelitian ini.

Berdasarkan hasil analisis data diketahui bahwa variabel kualitas sistem (SYSQUA), kualitas informasi (INQUA), penggunaan sistem (SYSUSE), dan kepuasan pengguna (USAT) secara simultan dan parsial berpengaruh terhadap dampak individual (INDPACT).

Ha1 : Kualitas sistem berpengaruh terhadap dampak individual.

Terdapat hubungan saling memengaruhi antara kualitas sistem terhadap dampak individual. Kualitas sistem yang baik berupa pemrosesan data akhir, kelancaran program yang digunakan, akses terhadap sistem yang digunakan, kemudahan pencarian data, fungsi dari setiap sistem, dokumentasi yang baik dari sistem yang digunakan, kemudahan penggunaan dan pembelajaran terhadap sistem, maupun terhadap kontrol akses atas sistem operasional yang digunakan berpengaruh terhadap dampak individual yang berupa peningkatan atau penurunan kinerja dan perilaku karyawan yang menggunakan sistem tersebut.

Hasil penelitian ini konsisten dengan hasil penelitian sebelumnya oleh Kositanurit, et al. (2006:561) juga menyatakan bahwa kualitas sistem berpengaruh terhadap dampak individual, atau kualitas sistem berpengaruh terhadap kinerja daripada pengguna sistem tersebut. Hasil penelitian ini tidak konsisten dengan hasil uji hipotesis Widodo, dkk (2013:94) yang menyatakan bahwa kualitas sistem tidak berpengaruh terhadap dampak individual atau kinerja individu.

Ha2 : Kualitas informasi berpengaruh terhadap dampak individual. 
Hasil uji hipotesis dalam penelitian ini menunjukkan bahwa kualitas sistem berpengaruh terhadap dampak individual. Kualitas informasi yang terkandung didalamnya yakni ketepatan waktu, output yang diinginkan, pemahaman yang baik terhadap sistem, memenuhi kebutuhan user, menghasilkan informasi yang dibutuhkan, dan kelengkapan informasi yang didapat berpengaruh terhadap dampak individual atau kinerja pengguna sistem tersebut.

Hasil uji hipotesis ini konsisten dengan hasil uji hipotesis Kositanurit, et al. (2006:561), dan Widodo, dkk. (2013:94) yang menyatakan bahwa kualitas informasi berpengaruh terhadap dampak individual.

Ha3 : Penggunaan sistem berpengaruh terhadap dampak individual.

Hasil uji hipotesis dalam penelitian ini menunjukkan bahwa penggunaan sistem berpengaruh terhadap dampak individual. Hasil uji indikator penggunaan sistem yang terkandung didalamnya berupa niat menggunakan aplikasi, prediksi keinginan untuk menggunakannya lain waktu, berencana untuk menggunakan sistem tersebut lagi, niat menggunakan sistem karena dapat diandalkan dan konsistensi pengguna menghasilkan hasil yang berpengaruh terhadap dampak individual atau kinerja daripada pengguna sistem tersebut.

Hasil uji hipotesis dalam penelitian ini konsisten dengan hasil uji hipotesis BurtonJones dan Straub (2006), dan Kositanurit, et al. (2006) yang menyatakan bahwa penggunaan sistem berpengaruh terhadap dampak individual atau kinerja daripada pengguna sistem tersebut. Hasil uji penelitian tidak konsisten dengan hasil uji hipotesis menurut McGill, et al. (2003:37), Iivari (2005:16), dan Widodo, dkk. (2013:95) yang menyatakan bahwa penggunaan sistem tidak berpengaruh terhadap dampak individual.

Ha4 : Kepuasan pengguna berpengaruh terhadap dampak individual.

Hasil uji hipotesis dalam penelitian ini menunjukkan bahwa kepuasan pengguna berpengaruh terhadap dampak individual. Indikator yang terkandung di dalam kepuasan pengguna yakni efisiensi, efektifitas, hasil yang diharapkan, user friendly, dan kepuasan pengguna sistem menghasilkan hasil yang berpengaruh terhadap dampak individual atau kinerja karyawan.

Hasil penelitian ini konsisten dengan hasil uji hipotesis menurut McGill, et al. (2003:36), Iivari (2005:16), dan Widodo, dkk. (2013:95) yang menyatakan bahwa kepuasan pengguna berpengaruh terhadap dampak individual.

Keseluruhan hasil daripada penelitian yang telah dilakukan dapat diringkas dan dilihat pada tabel yang disajikan berikut serta perbandingan hasil uji t terhadap hasil penelitian para peneliti terdahulu. Berikut ini adalah tabel kesimpulan seluruh hasil uji hipotesis penelitian.

Tabel 13. Perbandingan Hasil Uji Hipotesis Penelitian

\begin{tabular}{|c|c|c|c|c|c|c|}
\hline \multirow{2}{*}{$\begin{array}{c}\text { No } \\
\text {. }\end{array}$} & \multirow[b]{2}{*}{ Hubungan } & \multirow{2}{*}{$\begin{array}{c}\text { Hasil } \\
\text { Penelitian }(t- \\
\text { test sig. }< \\
0.05)\end{array}$} & \multicolumn{3}{|c|}{ Penelitian Terdahulu } & \multirow{2}{*}{$\begin{array}{c}\text { Perbandingan } \\
\text { Hasil } \\
\text { Penelitian }\end{array}$} \\
\hline & & & Peneliti & value & $\begin{array}{c}\text { Hasi } \\
1\end{array}$ & \\
\hline 1. & $\begin{array}{l}\text { SYSQUA } \rightarrow \\
\text { INDPACT }\end{array}$ & 0.003 & $\begin{array}{l}\text { Kositanurit, et al. } \\
\text { (2006) } \\
\text { Widodo, dkk. (2013) }\end{array}$ & $\begin{array}{c}0.000 \\
0.281^{*}\end{array}$ & $\begin{array}{l}+ \\
-\end{array}$ & $\begin{array}{l}\text { Konsisten } \\
\text { Tidak } \\
\text { Konsisten }\end{array}$ \\
\hline 2. & INQUA $\rightarrow$ & 0.031 & Kositanurit, et al. & 0.000 & + & Konsisten \\
\hline
\end{tabular}




\begin{tabular}{|c|c|c|c|c|c|c|}
\hline & INDPACT & & $\begin{array}{l}\text { (2006) } \\
\text { Widodo, dkk. (2013) }\end{array}$ & $2.416^{*}$ & + & Konsisten \\
\hline 3. & $\begin{array}{l}\text { SYSUSE } \rightarrow \\
\text { INDPACT }\end{array}$ & 0.006 & $\begin{array}{l}\text { McGill, et al. (2003) } \\
\text { Iivari (2005) } \\
\text { Burton-Jones and } \\
\text { Straub (2006) } \\
\text { Kositanurit, et al. } \\
\text { (2006) } \\
\text { Widodo, dkk., (2013) }\end{array}$ & $\begin{array}{c}-1.547 \\
0.15 \\
9.57^{* *} \\
0.011 \\
0.028^{*}\end{array}$ & $\begin{array}{l}- \\
- \\
+ \\
+ \\
-\end{array}$ & $\begin{array}{l}\text { Tidak } \\
\text { Konsisten } \\
\text { Tidak } \\
\text { Konsisten } \\
\text { Konsisten } \\
\text { Konsisten } \\
\text { Tidak } \\
\text { Konsisten }\end{array}$ \\
\hline 4. & $\begin{array}{l}\text { USAT } \rightarrow \\
\text { INDPACT }\end{array}$ & 0.009 & $\begin{array}{l}\text { McGill, et al. (2003) } \\
\text { livari (2005) } \\
\text { Widodo, dkk., (2013) }\end{array}$ & $\begin{array}{l}5.735^{*} \\
* * \\
0.52^{* * *} \\
3.028^{*} \\
\end{array}$ & $\begin{array}{l}+ \\
+ \\
+\end{array}$ & $\begin{array}{l}\text { Konsisten } \\
\text { Konsisten } \\
\text { Konsisten }\end{array}$ \\
\hline
\end{tabular}

Keterangan:

* signifikan jika $t$-statistic $>$ t tabel (1.96) dengan software Smart PLS 2.0 M3 (pembulatan keatas 3 angka dibelakang koma), ${ }^{* *} \mathrm{p}<0.01,{ }^{* * *} \mathrm{p}<0.001$ (one tailed test).

\section{PENUTUP}

Simpulan. Berdasarkan hasil pengujian hipotesis maka dapat ditarik beberapa kesimpulan sebagai berikut:

Kualitas sistem dalam aplikasi operasional yang digunakan pengguna berpengaruh terhadap dampak individual daripada pengguna sistem dengan hasil uji t sebesar 0.003 . Semakin bagus dan berkualitas suatu sistem yang digunakan, maka kinerja daripada pengguna sistem tersebut juga ikut terpengaruhi dimana pengguna akan lebih senang menggunakan dan menghasilkan hasil kerja yang lebih bagus.

Kualitas informasi dalam aplikasi operasional yang digunakan pengguna berpengaruh terhadap dampak individual dengan hasil uji t sebesar 0.031. Sehingga semakin bagus kualitas informasi yang dihasilkan oleh sistem yang digunakan, semakin bagus juga kinerja yang dihasilkan. Sebaliknya, jika kualitas informasi yang dihasilkan sistem tersebut tidak bagus yang akan berdampak pada individual dimana kinerja dari pengguna sistem menurun dan hasil kerja yang kurang memuaskan.

Penggunaan Sistem dalam aplikasi operasional yang digunakan berpengaruh terhadap dampak individual dengan hasil uji t sebesar 0.006. Jika user merasa nyaman dan secara terus-menerus atau mempunyai niat dan berkeinginan menggunakan sistem yang terkait, maka efek dari penggunaan sistem akan memengaruhi dampak individual pengguna atau memengaruhi kinerja yang dihasilkan dari penggunaan sistem tersebut yang didukung oleh sistem yang berkualitas. Kepuasan pengguna berpengaruh terhadap dampak individual dengan hasil uji t sebesar 0.009. Kepuasan tersebut dapat ditunjukkan dari efektivitas, efisiensi, serta hasil yang diharapkan dari penggunaan sistem tersebut. Dampak daripada kepuasan tersebut berpengaruh terhadap dampak individual atau kinerja pengguna sistem, dimana pengguna yang puas terhadap sistem yang digunakan akan lebih nyaman, efisien maupun efektif dari segi kinerja yang dihasilkan.

Hasil kajian literatur dalam penelitian ini dapat dikemukakan bahwa kualitas sistem, kualitas informasi, penggunaan sistem, dan kepuasan pengguna berpengaruh terhadap dampak individual. Kemampuan persamaan regresi yang dapat menjelaskan variabel 
dalam penelitian ini sebesar $59.10 \%$, sementara itu sisanya $40.90 \%$ dijelaskan oleh variabel lain.

Saran. Hasil penelitian ini menunjukkan keempat variabel independen yang diteliti yakni kualitas sistem, kualitas informasi, penggunaan sistem, dan kepuasan pengguna berpengaruh terhadap dampak individual atau mempengaruhi kinerja daripada pengguna sistem (karyawan). Upaya yang dilakukan untuk meningkatkan kinerja seluruh karyawan bukan hanya dari sistem yang digunakan, tetapi karyawan sendiri harus didukung oleh kemampuan spiritual, emosional, dan intelektual yang baik terutama dalam menangani nasabah.

Keterbatasan-keterbatasan dalam penelitian ini diharapkan dapat diperbaiki oleh peneliti selanjutnya. Penelitian selanjutnya diharapkan dapat menggunakan variabel lain selain variabel yang digunakan dalam penelitian ini karena masih banyak variabel lain yang dapat memengaruhi dampak individual yang diukur dari keberhasilan implementasi sistem. Penelitian selanjutnya juga diharapkan dapat menggunakan data yang berkelanjutan dari setiap periode atau penelitian ini menggunakan data cross sectional, yang artinya karakteristik responden dianalisis pada waktu tertentu saja. Sehingga penelitian selanjutnya mempunyai data yang berkelanjutan untuk mengukur dampak individual secara konsisten secara berkala. Penelitian selanjutnya diharapkan memfokuskan responden untuk satu responden saja (satu bank) saja. Hal ini dikarenakan prosedur, dan kebijakan setiap bank berbeda-beda yang secara otomatis memengaruhi karyawan bersangkutan. Perlu diingat juga sistem yang digunakan setiap bank sangat berbeda terutama sistem pada bank swasta dan bank negeri.

\section{DAFTAR RUJUKAN}

Abugabah, Ahed J.; Sanzogni, Louis; and Poropat, Arthur E.(2009) The Impact of Information Systems on User Performance: A Critical Review and Theoretical Model. International Conference on Computer Science and Engineering (ICCSE 2009). hal. 809-819

Burton-Jones, Andrew, and Straub, Detmar W. (2006) Reconceptualizing System Usage: An Approach and Empirical Test. Information Systems Research 17.(3). hal. 228-246

Daito, Apollo.(2011) Pencarian Ilmu Melalui Pendekatan Ontologi, Epistimologi, Aksiologi. Edisi 1. Jakarta: Mitra Wacana Media

DeLone, William H. and McLean, Ephraim R.(1992) Information Systems Success: The Quest for the Dependent Variable. Information System Research.3.(1). Hal. 60-95 .(2003) The DeLone and McLean Model of Information System Success: A TenYear Update. Journal of Management Information System 19.(4). hal. 9-30

Freeze, Ronald D.; Alshare, Khaled A.; Lane, Peggy L. and Wen, H. J.(2010) IS Success Model in E-Learning Context Based on Students' Perceptions. Journal of Information Systems Education 21.(2). hal. 173-184

Gelinas, Ulric J.; Dull, Richard B. and Wheeler, Patrick B.(2012) Accounting Information Systems. $9^{\text {th }}$ ed. Mason, OH: South-Western/Cengage Learning

Ghozali, Imam. (2008) Model Persamaan Struktural Konsep dan Aplikasi dengan Program Amos 16. Edisi 3. Semarang: Universitas Diponegoro .(2011) Aplikasi Analisis Multivariate dengan Program IBM SPSS 20. Edisi 6. Semarang: Badan Penerbit Universitas Diponegoro 
Goodhue, Dale L. and Thompson, Ronald L.(1995) Task-Technology Fit and Individual Performance. MIS Quarterly 19.(2). hal. 213-236

Hall, James A.(2013) Introduction to Accounting Information Systems. $8^{\text {th }}$ ed. United States: South-Western Cengage Learning

Iivari, Juhani. Spring (2005) An Empirical Test of the DeLone-Mclean Model of Information System Success. The DATA BASE for Advances in Information Systems 36.(2). hal. 8-27

Indriani, Mirna, dan Adryan, Reza (2009) Kualitas Sistem Informasi dan Kepuasan Pengguna Sistem Informasi Perguruan Tinggi Universitas Syiah Kuala. Jurnal Telaah \& Riset Akuntansi 2.(1). hal. 79-92

Ismail.(2010) Manajemen Perbankan dari Teori Menuju Aplikasi. Jakarta: Kencana

Istianingsih dan Wijanto, Hari S. (2008) Analisis Keberhasilan Penggunaan Perangkat Lunak Akuntansi Ditinjau dari Persepsi Pemakai (Studi Implementasi Model Keberhasilan Sistem Informasi). Jurnal Akuntansi dan Keuangan Indonesia 5.(1). hal. 50-76

.(2008) Pengaruh Kualitas Sistem Informasi, Perceived Usefulness, dan Kualitas Informasi Terhadap Kepuasan Pengguna Akhir Software Akuntansi. Simposium Nasional Akuntansi (SNA) ke XI Pontianak, 23-24 Juli 2008

Jogiyanto, Hartono. (2005) Analisis dan Desain Sistem Informasi. 3. Yogyakarta: Andi

Jumaili, Salman. (2005). Kepercayaan Terhadap Teknologi Sistem Informasi Baru dalam Evaluasi Kinerja Individual. SNA VIII, Solo. hal. 722-735

Komara, Acep. (2005) Analisis Faktor-faktor yang Mempengaruhi Kinerja Sistem Informasi Akuntansi. SNA 8, Solo. hal. 836-848

"Indikator Perdagangan di Bursa Efek Indonesia". Kompas. 20. 21 November 2014

Kositanurit, Boontaree; Ngwenyama, Ojelanki; and Osel-Bryson, Kweku-Muata.(2006) An Exploration of Factors that Impact Individual Perormance in an ERP Environment: An Analysis Using Multiple Analytical Techniques. European Journal of Information Systems 15. hal. 556-568

Kotler, Philip. (2002) Manajemen Pemasaran. Edisi Millenium. Jakarta: PT. Prenhallindo Laudon, Kenneth C. and Laudon, Jane P. (2012) Management Information Systems Managing the Digital Firm. $12^{\text {th }}$ ed. New Jersey: Prentice Hall

Mahdi, Salehi; Rostami, Vahab; Mogadam, Abdolkarim. (2010) Usefulness of Accounting Information System in Emerging Economy: Empirical Evidence of Iran. International Journal of Economics and Finance 2.(2). hal 186-195

Marakas, George M. and O'Brien, James A.(2013) Introduction to Information Systems. $16^{\text {th }}$ ed. New York: McGraw-Hill

McGill, Tanya; Hobbs, Valerie; and Klobas, Jane.(2003) User-Developed Applications and Information Systems Success: A test of DeLone and McLean Model. Information Resources Management Journal (ABI/INFORM Research) 16.(1). hal. 24-45

Mulyadi.(2008) Sistem Akuntansi. Edisi 4. Jakarta: Salemba Empat.

Negash, Solomon; Ryan, Terry; and Igbaria, Magid.(2003) "Quality and Effectiveness in Web-based Customer Support Systems." Information \& Management 40. hal. 757768 
Panagopoulos, Nikolaos. (2010) Sales Technology: Making the Most of Your Investment. New York: Business Expert Press, LLC

Petter, Stacie; DeLone, William; and McLean, Ephraim.(2008) Measuring Information Systems Success: Model, Dimensions, Measures, and Interrelationships. European Jurnal of Information Systems 17. hal. 236-263

Rahmawati, Diana.(2008) Analisis Faktor-faktor yang Berpengaruh Terhadap Pemanfaatan Teknologi Informasi. Jurnal Ekonomi \& Pendidikan 5.(1). hal. 107-118

Rai, Arun; Lang, Sandra S.; and Welker, Robert B.(2002) Assessing the Validity of IS Success Models: An Empirical Test and Theoretical Analysis. Information Systems Research 13.(1). hal. 50-69

Rai, I Gusti Agung.(2008) Audit Kinerja pada Sektor Publik: Konsep, Praktik, Studi Kasus. Jakarta: Salemba Empat

Roldán, José L. and Leal, Antonio.(2003) A Validation Test of an Adaptation of the DeLone and McLean's Model in the Spanish EIS Field. Idea Group Publishing. hal. 66-84

Romney, Marshall B. and Steinbart, Paul J.(2014) Accounting Information Systems. 13 ${ }^{\text {th }}$ ed. The United States of America: Pearson Educationrom

.(2012) Accounting Information Systems. $12^{\text {th }}$ ed. The United States of America: Pearson Education

Rudianto.(2009). Pengantar Akuntansi. Jakarta: Erlangga

Schmitt, Alexander. and Minker, Wolfgang.(2013). Towards Adaptive Spoken Dialog Systems. New York: Springer

Seddon, Peter B. (1997) A Respecification and Extension of the DeLone and McLean Model of IS Success. Information Systems Research 8.(3). hal. 240-253

Seddon, Peter B. and Kiew, Min-Yen.(1996) A Partial Test and Develompent of DeLone and McLean's Model of IS Success. Australasian Journal of Information Systems 4.(1). hal. 90-109

Simkin, Mark G.; Rose, Jacob M.; and Norman, Carolyn S. (2013) Accounting Information Systems. $12^{\text {th }}$ ed. Singapore: John Wiley \& Sons

Stone, R. W., Good, D. J. \& Baker-Eveleth, L., (2007) The Impact of Information Technology on Individual and Firm Marketing Performance Behaviour \& Information Technology. Behaviour \& Information Technology, 26(6), pp. 465-482

Sugiyono. (2012) Memahami Penelitian Kualitatif. Bandung: Alfabeta

Sutabri, Tata. (2005) Sistem Informasi Manajemen. Edisi 1. Yogyakarta: Andi

Tjakrawala, F.X. Kurniawan, dan Cahyo, Aldo. (2010) Adaptasi Model DeLone \& McLean yang Dimodifikasi Guna Menguji Keberhasilan Implementasi Software Akuntansi Bagi Individu Penggguna: Studi Empiris pada Perusahaan dalam Industri Barang Konsumsi uang Terdaftar di BEI. Simposium Nasional Akuntansi XIII Purwokerto 2010.

Warren, Carl S.; Reeve, James M.; and Fess, Philip E. (2005) Pengantar Akuntansi. Edisi 21. Jakarta: Salemba Empat

Widjajanto, N., (2008) Sistem Informasi Akuntansi. Jakarta: PT Gelora Aksara Pratama.

Widodo, Joko.(2005) Mendorong Birokrasi Berbasis Kinerja. 1. Malang: Bayumedia

Widodo, Tri W.; Handyani, Siti R.; dan Saifi, Muhammad. (2013) Pengaruh Aplikasi Sistem Informasi Manajemen (SIM) Terhadap Kinerja Karyawan (Studi Kasus pada 
Usaha Kecil Menengah Bidang Usaha Warnet di Kota Malang). Jurnal Profit 7.(1). hal. 87-100 